\title{
Stokastik Süreler İçeren Kapasite Kısıtlı Parti Büyüklüğü Belirleme Problemi
}

\author{
Duygu Taş ${ }^{1 *}$ \\ ${ }^{1}$ MEF Üniversitesi, Mühendislik Fakültesi, Endüstri Mühendisliği Bölümü, İstanbul, Türkiye (ORCID: 0000-0002-3579-4600)
}

(Illk Geliş Tarihi 1 Mayıs 2019 ve Kabul Tarihi 18 Haziran 2019)

(DOI: $10.31590 /$ ejosat.559645)

ATIF/REFERENCE: Taş, D. (2019). Stokastik Süreler İçeren Kapasite Kısıtlı Parti Büyüklüğü Belirleme Problemi. Avrupa Bilim ve Teknoloji Dergisi, (16), 441-453.

\section{$\ddot{O} \mathbf{z}$}

Bu makalede üretim ve kurulum süreleri stokastik olan kapasite kısıtlı çok ürünlü dinamik parti büyüklüğü belirleme problemi ele alınmıştır. Bu problemde tüm sürelerin stokastik olduğu durum göz önünde bulundurularak hem verimli hem de güvenilir üretim planları elde edilmektedir. Ele alınan problemin amacı klasik üretim maliyetleri ve ek mesai maliyetlerinden oluşan toplam maliyeti en küçüklemektir. Klasik maliyetler, üretim, kurulum ve envanter tutmaktan kaynaklanmaktadır. Ek mesai maliyetleri ise makinenin zaman kapasitesini aşacak şekilde kullanılmasından dolayı ortaya çıkmaktadır. Öncelikle, belirli bir üretim ve kurulum planı için beklenen ek mesai süresini kesin olarak hesaplayan bir prosedür önerilmiştir. Problemi etkin bir şekilde çözmek için tabu algoritmasına dayanan bir çözüm yaklaşımı geliştirilmiştir. Bu yaklaşım üç aşamadan oluşmaktadır: Başlangıç, iyileştirme ve planlama. Algoritmanın ilk aşamasında olurlu planlar üreten bir başlangıç metodu önerilmiş̧ir. Bulunan planlar makalede önerilen tabu arama metoduyla iyileştirilmektedir. Planlama aşamasında, yerel arama metodunun bulduğu çözümleri iyileştirmek için bir doğrusal programlama modeli geliştirilmiştir. Çözüm yöntemimizin performansı literatürde yayınlanmış alt sınırlar kullanılarak onaylanmıştır. Ayrıca, sonuçlar tabu arama yöntemimizin makul sürelerde çok iyi çözümler elde ederek iyi performans sergilediğini göstermektedir.

Anahtar Kelimeler: Parti büyüklüğü belirleme, Stokastik üretim zamanları, Stokastik kurulum zamanları, Ek mesai maliyetleri

\section{Capacitated Lot Sizing Problem with Stochastic Times}

\begin{abstract}
In this paper, we study a capacitated multi-item dynamic lot sizing problem with stochastic production and setup times. In this problem, we consider stochastic times to obtain production plans that are both efficient and reliable. The objective of the considered problem is to minimize the total cost including regular production costs and expected overtime costs. The regular costs result from production, setup and inventory holding. The expected overtime costs are incurred due to the excess usage of the machine capacity. First, a procedure that exactly computes the expected overtime for a given production and setup plan is developed. A solution procedure based on tabu search algorithm is proposed to effectively solve the problem. This procedure includes three main phases: initialization, improving, and scheduling. In the first phase of the algorithm, an initialization method is developed to construct feasible production plans. These plans are then improved by the proposed tabu search method. In the scheduling phase, a linear programming model is developed to further improve the solutions obtained by the local search method. The performance of our solution procedure is validated by the lower bounds reported in the literature. Moreover, results show that our tabu search method performs well by obtaining very good solutions in reasonable amount of times.
\end{abstract}

Keywords: Lot sizing problem, Stochastic production times, Stochastic setup times, Overtime costs.

* Sorumlu Yazar: MEF Üniversitesi, Mühendislik Fakültesi, Endüstri Mühendisliği Bölümü, İstanbul, Türkiye, ORCID: 0000-0002-3579-4600, duygu.tas@mef.edu.tr 


\section{Giriş}

Üretim planlama ve envanter yönetimi için önerilen modeller iki ana gruba ayrılmaktadır (bkz. Jans ve Degraeve, 2007, 2008). Birinci grupta sürekli zaman çizelgesi, sabit talep ve sonsuz zaman ufku içeren formülasyonlar vardır. Bu kategori altında, ekonomik sipariş miktarı belirleme ve ekonomik parti planlaması problemleri örnek verilebilir. İkinci grupta ise kesikli zaman çizelgesi, dinamik talep ve sonlu zaman ufkunu ele alan modeller bulunmaktadır. Daha belirgin olarak, zaman çizelgesi periyotlardan oluşmakta (örneğin, hafta ya da ay), ürünlerin talepleri her periyotta değişkenlik gösterebilmekte ve üretim planlaması belirli bir süre için yapılmaktadır. Bu özelliklere sahip olduğu için Parti Büyüklüğü Belirleme Problemi (PBBP) ikinci gruba dahildir.

Kapasite kısıtlı PBBP'de birçok farklı ürün aynı zaman periyodunda tek bir makine ile üretilebilmektedir ve amaç her ürünün talebini karşılayan en az maliyetli üretim planını elde etmektir. Daha belirgin olarak, problem her bir ürünün üretim zamanlarını ve üretim miktarlarını belirleyen en iyi planı bulmayı amaçlamaktadır. Problemin klasik tanımında üretim ve kurulum sürelerinin gerekirci olduğu farz edilmektedir. Diğer bir deyişle, matematiksel olarak bu problem gerekirci sürelerin makinenin zaman kapasitesine riayet edecek şekilde planlanmasına karşılık gelmektedir. Ancak, gerekirci çözümlerin niteliği sürelerin stokastik olduğu gerçek hayat problemlerine uygulandığında bozulur. Stokastik süreleri göz önünde bulundurmak, elde edilen planın zaman kapasitesine riayet edip etmediğini değerlendirmek için daha zengin bir stokastik kriter setine olanak sağlamaktadır. Bu stokastik kriterlerin tanımlanması ve PBBP'ye dahil edilmesi bu makalenin ana konusunu oluşturmaktadır.

Gerçek yaşam uygulamalarında üretim ve kurulum aşamalarında çeşitli sebeplerden kaynaklanan değişkenlikler mevcuttur. Operasyonel aşamada ortaya çıkan verimsizliğin üstesinden gelmek için literatüre PBBP'nin bazı stokastik versiyonları tanıtılmıştır. Stokastik problemler üzerine yazılmış tarama makaleleri için ilgili okuyucu Aloulou ve diğ. (2014), Brahimi ve diğ. (2017) ve Tempelmeier (2013) tarafından sunulan çalışmalara yönelebilir (detaylı literatür araştırması Bölüm 2'de sunulmaktadır). Bölüm 2'de de belirtildiği üzere stokastik versiyonlar çoğunlukla talep belirsizliğine (Bookbinder ve Tan, 1988; Brandimarte, 2006; Dellaert ve Melo, 1998; Jeunet ve Jonard, 2000; Koca ve diğ., 2015) ve stokastik makine bozulmalarına (Kuhn, 1997; Nourelfath, 2011) odaklanmıştır. Bu makalede ise bir olasılık dağılımını takip eden stokastik üretim ve kurulum sürelerini göz önünde bulunduran bir versiyon çalışılmaktadır. Stokastik süreleri kullanmak hem verimli hem de güvenilir üretim planları elde etmemize olanak sağlamaktadır. Üretim maliyetlerine ek olarak makinenin kapasitesinin üzerinde çalıştırılmasından kaynaklanan ek mesai maliyetleri de göz önünde bulundurulmaktadır.

$\mathrm{Bu}$ makalede tanıtılan probleme odaklanmamızı sağlayan motivasyon belirli bir aktivitenin uygulanması sırasında kendiliğinden her zaman var olan değişkenliktir. Stokastik süreleri planlama aşamasında göz önünde bulundurarak ve ele alınan probleme dahil edilen stokastik performans ölçümlerini kullanarak, üretim yapmak için harcanan sürenin doğru bir şekilde değerlendirilmesi sağlanmaktadır. Pratikte, bu değerlendirmeler makinenin kapasitesine göre yapılmaktadır. Gerçek hayat uygulamalarında üretim ve kurulum süreleri belirsiz oldukları ve bu sebeple tahmin edilemedikleri için makine kapasitesi potansiyel olarak esnektir. Sonuç olarak, pratik uygulamalarda makine çoğunlukla kapasitesini aşacak şekilde kullanılmaktadır.

Bu makalede çalışılan problem için Taş ve diğ. (2019) tarafindan literatüre tanıtılan model temel alınmaktadır. Taş ve diğ. (2019), PBBP için stokastik kurulum sürelerini göz önünde bulunduran yeni bir versiyon tanıtmışlardır. Önerdikleri modeli çözmek için etkili çalışan iki sezgisel metot geliştirmişlerdir. Ortalama numune yaklaşımı ile elde ettikleri alt ve üst sınırları kullanarak bu sezgisel yöntemlerin performans değerlendirmesini yapmışlardır. Bu makalede önerilen problem hem stokastik kurulum sürelerini hem de stokastik üretim sürelerini göz önünde bulundurduğu için, Taş ve diğg. (2019) tarafindan tanıtılan versiyonun genişletilmiş halidir. Problemin amacı klasik üretim maliyetleri ve ek mesai maliyetlerinden oluşan toplam maliyeti en küçüklemektir. Klasik maliyetler üç ana kısımdan oluşmaktadır. Bunlar üretim maliyetleri, kurulum maliyetleri ve envanter tutmaktan dolayı ortaya çıkan maliyetlerdir. Ek mesai maliyetleri ise makinenin zaman kapasitesini aşacak şekilde kullanılmasından kaynaklanmaktadır. Sürelerdeki belirsizlik bu maliyetleri hesaplarken göz önünde bulundurulmaktadır.

Ele alınan probleme eniyi olmasa da yüksek kaliteli sonuçlar üretmek için başlangıç, iyileştirme ve planlama aşamalarından oluşan bir çözüm yöntemi önermekteyiz. Başlangıç aşamasında bir gerekirci parti büyüklügü belirleme problemi kullanılmaktadır. Elde edilen çözüm tabu arama metoduyla iyileştirilmektedir. Tabu arama metodu içerisinde belirli iterasyonlarda kurulum değişkenleri sabit tutularak en iyi üretim ve envanter miktarlarını veren planlar bulunmakta, böylelikle yerel arama metodunun bulduğu sonuçlar için ileri iyileştirme sağlanmaktadır. Üretim ve kurulum sürelerindeki belirsizlik gerçek hayat problemleri için oldukça ilgili olmasına rağmen şimdiye kadar her iki sürenin stokastik olduğu bir araştırma yapılmamıştır. Dolayısıyla, bu makalede tanıtılan problem ve önerilen çözüm yöntemi ilgili literatürü genişletmektedir.

Makalenin geri kalanı şu şekilde düzenlenmiştir. PBBP’nin gerekirci ve stokastik versiyonlarının göz önünde bulundurulduğu literatür araştırması Bölüm 2'de verilmektedir. Çalışmada tanıtılan problem ve kullanılan formülasyonlar Bölüm 3'te anlatılmaktadır. Bölüm 4'te kurulum ve üretim sürelerinin özellikleri verilmektedir. Beklenen ek mesai süresini hesaplayan prosedür Bölüm 5 'te detaylı şekilde anlatılmaktadır. Bölüm 6'da önerilen çözüm yöntemleri ve Bölüm 7'de hesaplamalı sonuçlar sunulmaktadır. Son olarak, Bölüm 8'de ana bulgular ve ayrıca ileri araştırmalar için öneriler verilmektedir.

\section{Literatür Özeti}

Bu kısımda, literatürde çalışılmış gerekirci parti büyüklüğü belirleme problemleri, ve talep ve zamanların değişkenlik gösterdiği stokastik parti büyüklüğü belirleme problemleri ele alınmaktadır. Ek olarak, stokastik makina arızaları gibi üretim ortamı ile ilgili olan belirsizliklerin dikkate alındığı problemler de sunulmaktadır. Bölüm sonunda bu makalede çalışılan problemin tüm bu problemlerden farkları ayrıca belirtilmektedir. 
European Journal of Science and Technology

Tek ürünlü ve çok ürünlü kapasite kısıtlı parti büyüklüğü belirleme problemi NP-zor birleşimsel eniyileme problemleri sınıfina dahildir (Bitran ve Yanesse, 1982). Bu problem için literatürde etkin bir şekilde çalışan birçok eniyi ve sezgisel yöntem önerilmiştir. Brahimi ve diğ. (2006) tarafindan sunulan tarama makalesinde hem kapasite kısıtll hem kapasite kısıtsız tek ürünlü versiyonlar ele alınmaktadır. Jans ve Degraeve $(2007,2008)$ birçok parti büyüklüğ̈̈ belirleme problemi için geliştirilmiş mevcut matematiksel formülasyonların ve meta-sezgisel yaklaşımların anlatıldığı kapsamlı tarama makaleleri sunmaktadırlar. Buschkühl ve diğ. (2010) çok ürünlü dinamik parti büyüklüğü belirleme problemleri için önerilmiş modellere ve algoritmalara odaklanmakta, ve çeşitli eniyi ve yaklaşık metotları incelemektedirler.

Hindi ve diğ. (2003), ve Süral ve diğ. (2009) klasik PBBP için Lagrange gevşetmesine dayanan sezgisel metotlar geliştirmektedirler. İlgili okuyucu klasik PBBP modeline etkili alt sınırlar üreten prosedür ile ilgili detaylar için Jans ve Degraeve (2004) makalesine yönelebilir. Bu prosedür ağ formülasyonunun her bir zaman periyodu için alt problemlere ayrıştırılarak çözülmesine dayanmaktadır. Özdamar ve Birbil (1999), Özdamar ve Barbarosoğlu (1998), ve Barbarosoğlu ve Özdamar (2000) klasik PBBP için gerekirci ek mesai sürelerini ele almaktadırlar. Geliştirilen modeller benzetimli tavlama ve genetik algoritmasına dayanan sezgisel yöntemlerle çözülmektedir. Diaby ve diğ. (1992a,1992b) gerekirci ek mesai sürelerinin sınırlı olduğu versiyon için Lagrange gevşetmesine dayanan iki çözüm yöntemi geliştirmektedirler. Daha belirgin olarak, Diaby ve diğ. (1992a) bu iki çözüm yöntemini dalve-sınır algoritmasıyla birlikte, ve Diaby ve diğ. (1992b) sezgisel bir metotla birlikte uygulamaktadırlar.

Parti büyüklüğü belirleme problemlerinin stokastik versiyonları çoğunlukla talep belirsizliğine odaklanmaktadır. İlgili okuyucu, stokastik parti büyüklüğü belirleme problemleri üzerine hazırlanmış detaylı tarama çalışmaları için Tempelmeier (2013), ve Aloulou ve diğ. (2014) makalelerine yönelebilir. Bookbinder ve Tan (1988) stokastik talepleri ele almakta ve geliştirdikleri modelde $\alpha$-servis seviyesi kısıtlarını kullanmaktadırlar. Önerdikleri modelde, $\alpha$ envanterin eksi olmayan bir değer alma olasılığına karşlık gelmektedir. Bu çalışmalarında ayrıca statik belirsizlik, dinamik belirsizlik ve statik-dinamik belirsizlik olmak üzere üç strateji önermektedirler. Statik belirsizlik stratejisinde donmuş çizelgeleme fikri uygulanmaktadır. Diğer bir deyişle, bu stratejide zamanlama ve üretim seviyeleriyle ilgili tüm kararlar planlama ufkunun başında belirlenir. Bu makalede çalışılan problem için üretim miktarlarına ve makine kurulumlarına gerçek kurulum zamanları gözlemlenmeden önce karar verildiğini farz etmekteyiz. Daha belirgin olarak, bu uygulama Bookbinder ve Tan (1988) tarafindan önerilen statik belirsizlik stratejisine karşılık gelmektedir. Jeunet ve Jonard (2000), talepte görülen belirsizliğin üretim planları üzerindeki etkisini değerlendirmek için birkaç parti büyüklüğü belirleme tekniği önermektedirler. Bu değerlendirme maliyet açısından etkinlik ve dayanıklılık olmak üzere iki kritere göre yapılmaktadır. Simülasyon prosedürleriyle elde edilen sonuçlar bu iki kriterin negatif iniltili olduğunu göstermektedir. Brandimarte (2006), talep belirsizliğini yönlü senaryo ağacı kullanarak tasvir etmektedir ve bu gösterim telafi içeren stokastik çok-katlı karışık-tamsayılı programlama modeline karşılık gelmektedir. Önerilen formülasyon tesis-yerleşimi modeline dayanmaktadır. Bu formülasyon için sabitleme-vegevşetme metodunu kullanan bir sezgisel algoritma uygulanmaktadır. Elde edilen sonuçlara göre, talep belirsizliğini planlama aşamasında göz önünde bulundurmak kayda değer iyileştirmeler sağlamaktadır. Bu durum özellikle kapasite kısıtının çok sıkı olduğu problem örneklerinde daha belirgin olarak gözlemlenmektedir. Yakın zamanda, Koca ve diğ. (2015) stokastik taleplerin ve kontrol edilebilir üretim sürelerinin olduğu bir kapasite kısıtlı parti büyüklüğü belirleme problemini ele almaktadırlar. Spesifik olarak, her bir periyottaki talepler Normal dağılımı takip etmektedir. Ayrıca, dışarıdan kaynak temin ederek ya da makine hızı ayarlanarak üretim süreleri düşürülebilmektedir. Üretim sürelerindeki azaltma, kısaltma maliyetleri adı verilen ek maliyetlere sebep olmaktadır. Çalışmada kısaltma maliyeti fonksiyonunun dışbükey bir fonksiyon olduğu farz edilmektedir. Önerilen problem, Bookbinder ve Tan (1988) makalesinde geliştirilen statik belirsizlik stratejisi ve $\alpha$-servis seviyesi kısıtları kullanılarak çözülmektedir. Elde edilen sonuçlara göre, kapasite kısıtının orta seviyede olduğu ve yüksek kurulum maliyetlerinin göz önünde bulundurulduğu problem örnekleri için kontrol edilebilir üretim süreleri çok daha etkili çalışmaktadır.

Stokastik PBBP versiyonları çoğunlukla bir ürün, bir periyot ve bir makine içermektedir (Aloulou ve diğ, 2014). Beraldi ve di $\breve{g}$. (2006) özdeş paralel makineler ve stokastik üretim sürelerinin göz önünde bulundurulduğu bir versiyonu çalışmışlardır. Stokastik parametreler senaryo ağacı kullanılarak modellenmiştir ve problemi çözmek için çok katlı, karışık tam sayılı stokastik programlama formülasyonu önermişlerdir. $\mathrm{Bu}$ formülasyonu çözmek için sabitleme-ve-gevşetme metoduna dayanan sezgisel yöntemler geliştirilmiştir. Dellaert ve Melo (1998), sipariş usulü üretim ortamı için bir ürün içeren stokastik üretim sistemini ele almaktadırlar. Benzer stokastik versiyonlar için geliştirilmiş mevcut stratejiler, ek mesai maliyetleri göz önünde bulundurularak daha etkin hale getirilmektedir. Ek mesai ücretleri, toplam üretim süresinin makinenin kapasitesini aşması halinde ortaya çıkmaktadır. Bu sistemde, kapasite sadece üretim sürelerinden dolayı tüketilmektedir. Diğer bir deyişle kurulum süreleri ele alınmamaktadır. Önerdikleri versiyonda, stokastik bilgi kısmi müşteri siparişlerinden dolayı kaynaklanmaktadır. Eniyi parti büyüklüğüne yakın sonuçlar veren birçok prosedür önerilmektedir. Bu yöntemler, literatürde stok için üretim problemini çözmede sıkça kullanılan $(s, S)$ ve $(R, S)$ metotlarına dayanmaktadır.

Stokastik sürelerin veya stokastik makine bozulmalarının göz önünde bulundurulduğu problemler ise oldukça yakın zamanda az sayıda çalı̧̧mada ele alınmıştır. Taş ve dĭg. (2019) stokastik kurulum sürelerinin ele alındığı çok ürünlü kapasite kısıtlı parti büyüklüğü belirme problemini çalışmışlardır. Verilen kapasitenin, kurulum sürelerinin gerçekleştiği andaki değerlerinden dolayı yetersiz kalması halinde şirketin ek mesai kullanabildiği farz edilmektedir. Bu problem için gerekirci modellerin belirli parametrelerinin değiştirilmesi prensibine dayanan iki tane sezgisel metot önerilmektedir. Ayrıca, amaç fonksiyonun üst ve istatistiksel alt sınırlarını hesaplamak için ortalama numune yaklaşımı geliştirilmektedir. Kuhn (1997) bir ürün içeren kapasite kısıtsız parti büyüklüğü belirleme problemini stokastik makine bozulmalarıla ele almaktadır. Bu problem için iki durum göz önünde bulundurulmaktadır: (i) makine bozulduktan sonra kurulum tamamen zayi olur ve yeni bir kurulum gerekir, (ii) makine bozulduktan sonra aynı ürünün üretimini devam ettirmenin maliyeti orijinal kurulum maliyetinden çok daha ucuzdur. Çözüm yöntemi olarak, her iki durum için de eniyi üretim planını elde eden stokastik dinamik programlama modelleri önerilmektedir. Nourelfath (2011) çok ürün ve çok periyot içeren kapasite kısıtlı dinamik parti büyüklüğü belirleme problemini çalışmaktadır. Bu problemde, makine 
bozulmalarının stokastik oldukları farz edilmektedir ve kapasite sadece üretim sürelerinden dolayı tüketilmektedir. Diğer bir deyişle, kurulum süreleri ele alınmamaktadır. Önerilen model, müşteri hizmet seviyesini önceden belirlenmiş bir değer dahilinde karşılamayı sağlayacak bir dizi olasılıksal kısıtlamalar içerir ve iki aşamalı bir yöntemle çözülmektedir.

Bu makalede, kapasite kısıtlı çok ürünlü dinamik parti büyüklüğü belirleme probleminin stokastik bir versiyonunu çalışmaktayız. $\mathrm{Bu}$ versiyonda, kurulum ve üretim süreleri bilinen bir olasılık dağılımına göre değişkenlik göstermektedir. Amaç, toplam beklenen maliyeti (klasik üretim maliyetleri ve beklenen ek mesai maliyetleri) enküçükleyen bir üretim planı elde etmektir. Ek mesai maliyetleri, makinenin zaman kapasitesini aşacak şekilde kullanımından dolayı kaynaklanmaktadır. Verimli sonuçlar elde etmek için tabu metoduna dayanan ve başlangıç, iyileştirme ve planlama aşamalarından oluşan bir çözüm yaklaşımı önerilmektedir. Bu makalede ele alınan stokastik versiyon ve önerilen çözüm yöntemleri, şimdiye kadar başka parametrelerdeki belirsizliği çalışmış olan problemleri (bkz. talepler, sadece kurulum süreleri, sadece üretim süreleri ve makine bozulmaları) ve mevcut çözüm yöntemlerini geliştirmektedir. Diğger bir deyişle, bu çalışmayla literatürdeki gerçek hayat uygulamalarına ilişkin önemli boşluklar doldurulmaktadır.

\section{Problem Tanımı ve Formülasyon}

Klasik PBBP modellerinde $P=\{1, \ldots, n\}$ ürün kümesini ve $T=\{1, \ldots, m\}$ zaman periyodu kümesini simgelemektedir. Birçok ürün aynı zaman periyodunda üretilebilmektedir ve bütün ürünler için her $t$ zaman periyodunda kısıtlı üretim kapasitesi olan $\left(C_{t}\right)$ tek bir makine kullanılmaktadır. Herhangi bir periyotta ürün $i$ için üretim başlarsa o ürün için maliyeti $s c_{i}$ olan ve kapasiteden $s t_{i}$ birim kullanan makine kurulumu yapılması gerekmektedir. Diğer bir deyişle, $s t_{i}$ gerekirci kurulum süresine karşlık gelmektedir. Ürün $i$ 'den bir birim üretmek $v c_{i}$ maliyetine ve kapasiteden $v t_{i}$ birim kullanılmasına sebep olmaktadır. Diğer bir deyişle, $v t_{i}$ gerekirci birim üretim süresine karşılık gelmektedir. Ürün $i$ için periyot sonunda bir birim envanter bulundurma $h c_{i}$ maliyetini beraberinde getirmektedir. Ayrıca, her ürün için $(i)$ her periyot içerisinde $(t)$ karşılanması gereken talep bilinmektedir $\left(d_{i t}\right)$.

$\mathrm{Bu}$ tanımlardan sonra kapasite kısıtlı çok ürünlü dinamik PBBP için tanıtılan standart formülasyon (Model-SF) aşağıdaki şekilde verilmektedir. Bu modelde, $x_{i t}$ ürün $i$ 'den periyot $t$ içerisinde üretilen birim sayısını, $y_{i t}$ ürün $i$ ve periyot $t$ ile ilişkilendirilmiş ikili kurulum değişkenini ve $s_{i t}$ ürün $i$ 'den periyot $t$ sonunda elde kalan birim sayısını (periyot sonu envanter) göstermektedir. Bu modelin amacı (1) toplam üretim, kurulum ve envanter maliyetlerini enküçültmektir. (2) kısıt kümesi, kütle dengesi denklemlerine karşl1ık gelmektedir: Her ürün $i$ için $t$ periyodundaki talep o periyotta yapılan üretim ve bir önceki periyottan aktarılan envanterle karşılanır, artan miktar bir sonraki periyotta kullanılacak olan envanteri oluşturur. (3) kısıt kümesi, herhangi bir periyotta bir ürünün üretilmesinin o ürün için o periyotta bir kurulum gerektirdiğini belirtmektedir. Bu kısıt kümesinde $M$ çok büyük bir sayıya karşlık gelmektedir ve değeri $\sum_{j=t}^{m} d_{i j}$ formülü kullanılarak belirlenir. Diğer bir deyişle, ürün $i$ için periyot $t$ içerisinde yapılacak olan üretim, kalan talep (periyot $t$ 'den periyot $m$ 'ye kadar karşılanması gereken toplam talep) tarafından sınırlandırılmaktadır. (4) kısıt kümesi, her bir periyotta toplam üretim ve kurulum süresinin makine kapasitesini geçmemesini sağlamaktadır. (5) kısıt kümesine ardısmarlamaya izin verilmediği için ihtiyaç duyulmaktadır. (6) ve (7) kısıt kümeleri sırasıyla, üretim ve kurulum değişkenlerinin değer alanını belirtmektedir.

$$
\begin{array}{ll}
\min \sum_{i \in P} \sum_{t \in T} v c_{i} x_{i t}+s c_{i} y_{i t}+h c_{i} s_{i t} \\
s_{i, t-1}+x_{i t}=d_{i t}+s_{i t}, & i \in P, t \in T, \\
x_{i t} \leq M y_{i t}, & i \in P, t \in T, \\
\sum_{i \in P} v t_{i} x_{i t}+s t_{i} y_{i t} \leq C_{t}, & i \in P, t \in T, \\
s_{i t} \geq 0, & i \in P, t \in T, \\
x_{i t} \geq 0, & i \in P, t \in T, \\
y_{i t} \in\{0,1\}, & i \in P, t \in T .
\end{array}
$$

\subsection{Stokastik Parti Büyüklüğü Belirleme Problemi}

$\mathrm{Bu}$ makalede bilinen bir olasılık dağılımına göre değişkenlik gösteren stokastik üretim ve stokastik kurulum zamanları ele alınmaktadır. Üretim miktarlarına ve uygulanacak olan makine kurulumlarına gerçek üretim ve kurulum süreleri bilinmeden önce karar verildiği farz edilmektedir. Diğer bir deyişle, problem donmuş çizelgelemeye göre çözülmektedir. Bu uygulama Bookbinder ve Tan (1988) tarafindan literatüre tanitılan statik belirsizlik stratejisine karşllık gelmektedir. Daha belirgin olarak, gerçek üretim ve kurulum süreleri ürünler üretildiği anda ortaya çıkmaktadır. Planlama aşamasında elde edilen üretim planı operasyonel aşamada değiştirilmemekte, ama makinenin zaman kapasitesinin yeterli olmadığı durumlarda ek mesai kullanımına başvurulmaktadır. Bundan dolayı, amaç fonksiyonuna beklenen ek mesai süresinden kaynaklanan ilave bir maliyet eklenmektedir. 
Bu çalışmada, Taş ve diğ. (2019) tarafindan literatüre tanıtılan ve sadece stokastik kurulum sürelerini göz önünde bulunduran modele odaklanılmıştır. Modelde ek mesai süresinin hesaplanması önemli bir adımı oluşturmaktadır. Bu makalede ele alınan problemde üretim süreleri de stokastik olduğu için bu unsurun yeni probleme göre hesaplanması literatüre önemli bir katkı sağlamaktadır.

Stokastik üretim ve kurulum sürelerini içeren model (Model-SSM) aşağıdaki şekilde tanımlanmaktadır.

$$
\begin{array}{cc}
\min \sum_{i \in P} \sum_{t \in T}\left(v c_{i} x_{i t}+s c_{i} y_{i t}+h c_{i} s_{i t}\right)+\sum_{t \in T} o c_{t} o_{t}\left(\mathbf{x}_{\mathbf{t}}, \mathbf{y}_{\mathbf{t}}\right) \\
s_{i, t-1}+x_{i t}=d_{i t}+s_{i t}, & i \in P, t \in T, \\
x_{i t} \leq M y_{i t}, & i \in P, t \in T, \\
s_{i t} \geq 0, & i \in P, t \in T, \\
x_{i t} \geq 0, & i \in P, t \in T, \\
y_{i t} \in\{0,1\}, & i \in P, t \in T .
\end{array}
$$

Yukarıdaki modelin amacı (8) iki kısımdan oluşan toplam beklenen maliyeti en küçültmektir. İlk kısım üretim, kurulum ve envanterden kaynaklanan klasik üretim maliyetidir. İkinci kısım ise beklenen ek mesaiden kaynaklanan maliyettir. Kapasitenin esnek kısıt olarak ele alınması beklenen ek mesai maliyetinin amaç fonksiyonuna eklenmesini sağlamaktadır. Diğer bir deyişle, standart formülasyonda olan (4) kısıt kümesi bu modele dahil edilmemektedir. Ancak, kapasite kısıtı dolaylı olarak beklenen ek mesai süresinin hesaplanmasında göz önünde bulundurulmaktadır. Modeldeki kısıtlar talep (9), kurulum (10) ve değişkenlerin değer alanları (11-13) ile ilgilidir. Bu formülasyon telafi içeren iki aşamalı stokastik programlamaya karşllık gelmektedir (Birge ve Louveaux, 2011). Diğer bir deyişle, üretim ve kurulum kararları ilk aşama kararlarına ve ek mesai süreleri de ikinci aşama kararlarına karşlık gelmektedir.

Bu modelde, $O_{t}\left(\mathbf{x}_{t}, \mathbf{y}_{t}\right)$ periyot $t$ içerisinde gerçekleştirilen üretim planının beklenen ek mesai süresine karşıllık gelmektedir. $\mathbf{x}_{t}$ ve $\mathbf{y}_{t}$ birer vektördür ve şu şekilde tanımlanmaktadır: $\mathbf{x}_{t}=\left\{x_{i t} \mid i \in P\right\}$ ve $\mathbf{y}_{t}=\left\{y_{i t} \mid i \in P\right\}$. Bu vektörler sırasıyla periyot $t$ içerisinde her üründen kaç birim üretildiğini ve karşıllk gelen makine kurulumlarını göstermektedir.

\section{Stokastik Sürelerin Özellikleri}

Bu makalede üretim ve kurulum sürelerinin Gama dağılımını takip ettiği farz edilmektedir. Gama dağılımında büyük değerlerin görülme ihtimali küçüktür. Bu varsayım problemde ele alınan süreler için oldukça gerçekçidir. Ayrıca, bu dağılımın toplamsal özelliği beklenen ek mesai sürelerini hesaplamada çok önemli bir rol oynamaktadır. Gama dağılımını takip eden değişkenler eksi değer alamazlar. Bir başka önemli nokta da Üstel, Erlang ve Ki-kare gibi dağılımların Gama dağılımının özel bir haline karşılık gelmeleridir.

Birim (üretim ya da kurulum) sürenin $T$ ile gösterildiğini ve bu sürenin şekil parametresi $\alpha$ ve ölçek parametresi $\lambda$ olan Gama dağılımı ile ifade edildiğini varsayalım. Bu durumda, karşılık gelen olasılık yoğunluk fonksiyonu ve kümülatif dağılım fonksiyonu aşağıdaki şekilde tanımlanmaktadır.

$$
\begin{gathered}
f(w)=\frac{e^{-\mathrm{w} / \lambda} \mathrm{w}^{\alpha-1}}{\Gamma(\alpha) \lambda^{\alpha}} \\
F(\delta)=\operatorname{Prob}(w \leq \delta)=\Gamma_{\alpha, \lambda}(\delta)=\int_{0}^{\delta} \frac{e^{-z / \lambda} z^{\alpha-1}}{\Gamma(\alpha) \lambda^{\alpha}} d z
\end{gathered}
$$

Yukarıdaki tanımlamalarda, değişkenlerin değer alanları şu şekildedir: $w \geq 0, \delta \geq 0$ ve $\Gamma(\alpha)=\int_{0}^{\infty} e^{-r} r^{\alpha-1} d r$. Bu makalede önerilen yaklaşımda, periyot $t$ içerisinde ürün $i$ 'den $x_{i t}$ adet üretmek için harcanan toplam rassal süre $V_{i t}$ ile gösterilmektedir ve bu süre $\left(v t_{i} x_{i t}\right)$ tane birim rassal değişkenin toplamı olarak tanımlanmaktadır. Diğer bir deyişle, $V_{i t}$ değişseni ürün $i$ için harcanan toplam rassal süreyi belirtmektedir ve her birinin Gama dağılımını takip ettiği birim sürelere bölünmektedir. Ek olarak, bu değişkenlerin bağımsız ve aynı dağılımı gösterdikleri farz edilmekte ve bu varsayım $V_{i t}=\sum_{b=1}^{v t_{i} x_{i t}} T$ tanımını beraberinde getirmektedir. Bu modelleme, toplamsal özelliğinin yardımıla Gama dağılımı ile ifade edilen üretim zamanlarını türetmeyi sağlamaktadır. Daha belirgin olarak, $V_{i t}$ şekil parametresi $\alpha\left(v t_{i} x_{i t}\right)$ ve ölçek parametresi $\lambda$ olan Gama dağılımı ile tanımlanmaktadır.

Bu değişkenin ortalama ve değişinti değerleri aşağıdaki şekilde hesaplanmaktadır. 


$$
\begin{gathered}
E\left[V_{i t}\right]=\alpha \lambda\left(v t_{i} x_{i t}\right) \\
\operatorname{Var}\left(V_{i t}\right)=\alpha \lambda^{2}\left(v t_{i} x_{i t}\right)
\end{gathered}
$$

Benzer şekilde $S_{i t}$ periyot $t$ içerisinde ürün $i$ için makine kurulumundan dolayı harcanan rassal süreyi göstermektedir ve bu süre $s t_{i}$ tane birim rassal değiş̧kenin toplamı olarak tanımlanmaktadır. Bu değişkenlerin bağımsız ve aynı dağılımı gösterdikleri varsayımı $S_{i t}=\sum_{b=1}^{s t_{i}} T$ tanımını beraberinde getirmektedir. Diğer bir deyişle, $S_{i t}$ şekil parametresi $\alpha s t_{i}$ ve ölçek parametresi $\lambda$ olan Gama dağılımı ile tanımlanmaktadır. Bu değişkenin ortalama ve değişinti değerleri aşağıdaki şekilde hesaplanmaktadır.

$$
\begin{gathered}
E\left[S_{i t}\right]=\alpha \lambda s t_{i} \\
\operatorname{Var}\left(S_{i t}\right)=\alpha \lambda^{2} s t_{i}
\end{gathered}
$$

$\mathrm{Bu}$ çalışmada, her ürün için beklenen üretim süresi $\left(E\left[V_{i t}\right]\right)$ ve beklenen kurulum süresinin $\left(E\left[S_{i t}\right]\right)$ orijinal değerlerine $\left(v t_{i}\right.$ ve $s t_{i}$ ) eşit olması için $\alpha \lambda=1$ uygulanmaktadır. Daha belirgin olarak, $\alpha \lambda=1$ koşulu stokastik sürelerin ortalama değerlerinin bu değişkenlerin klasik problemde tanımlanan gerekirci değerlerine eşit olmasını sağlamaktadır. İlgili okuyucu benzer uygulamalar için Taş ve di ̌̆ . $(2013$, 2019) makalelerine yönelebilir. Bu yaklaşım, önerilen stokastik problem ve çözüm yaklaşımı tarafından elde edilen sonuçların literatürde tanıtılmış gerekirci ve stokastik modellerin sonuçlarıyla adil bir şekilde karşılaştırılmasını sağlamaktadır.

\section{Beklenen Ek Mesai Süresi}

Periyot $t$ içerisinde üretilen ürünlerin üretimleri ve makine kurulumları için harcanan toplam süre $\left(Z_{t}\right)$ aşağıdaki şekilde tanımlanmaktadır:

$$
Z_{t}=\sum_{i \in P_{t}} V_{i t}+S_{i t}
$$

Yukarıdaki tanımlamada, $P_{t}$ periyot $t$ içerisinde üretilen ürünleri gösteren kümeye karşıllk gelecektir. Diğer bir deyişle, $P_{t}=$ $\left\{i \mid y_{i t}=1, i \in P\right\}$ şeklinde tanımlanmaktadır. (20) denkleminden kolayca görüleceği üzere $Z_{t}$ periyot $t$ içerisinde üretilen ürünlerin rassal üretim ve kurulum sürelerinin toplamına karşılık gelmektedir. Bu süreler bağımsız ve aynı dağılımı gösterdikleri için $Z_{t}$ değiş̧keni de Gama dağılımı ile tanımlanmaktadır. Bu değişkenin şekil parametresi ve ölçek parametresi aşağıdaki şekilde hesaplanmaktadır:

$$
\begin{gathered}
\alpha_{t}=\alpha \sum_{i \in P_{t}}\left(v t_{i} x_{i t}\right)+s t_{i} \\
\lambda_{t}=\lambda
\end{gathered}
$$

Bu özelliklere göre beklenen ek mesai süresi (23) denklemiyle tanımlanmaktadır. İlgili okuyucu benzer prosedürler için Dellaert ve diğ. $(2000)$ ve Taş ve diğ. $(2013,2019)$ tarafından sunulan çalışmalara yönelebilir.

$$
O_{t}\left(\boldsymbol{x}_{t}, \boldsymbol{y}_{t}\right)=\int_{C_{t}^{\prime}}^{\infty}\left(u-C_{t}^{\prime}\right) \frac{e^{-u / \lambda_{t}} u^{\alpha_{t}-1}}{\Gamma\left(\alpha_{t}\right) \lambda_{t}^{\alpha_{t}}} d u
$$

Yukarıdaki tanıma göre (23) denklemi aşağıdaki şekilde yazılabilir:

$$
O_{t}\left(\boldsymbol{x}_{t}, \boldsymbol{y}_{t}\right)=\int_{C_{t}^{\prime}}^{\infty} \frac{e^{-u / \lambda_{t}} u^{\alpha_{t}}}{\Gamma\left(\alpha_{t}\right) \lambda_{t}{ }^{\alpha_{t}}} d u-\int_{C_{t}^{\prime}}^{\infty} C_{t}^{\prime} \frac{e^{-u / \lambda_{t}} u^{\alpha_{t}-1}}{\Gamma\left(\alpha_{t}\right) \lambda_{t}{ }^{\alpha_{t}}} d u
$$

Gama dağılımının özellikleri kullanılarak beklenen mesai süresi

$$
O_{t}\left(\mathbf{x}_{t}, \mathbf{y}_{t}\right)=\alpha_{t} \lambda_{t}\left(1-\Gamma_{\alpha_{t}+1, \lambda_{t}}\left(C_{t}^{\prime}\right)\right)-C_{t}^{\prime}\left(1-\Gamma_{\alpha_{t}, \lambda_{t}}\left(C_{t}^{\prime}\right)\right)
$$

kullanılarak hesaplanmaktadır. Yukarıdaki denklemlerde $C_{t}^{\prime}$ arta kalan gerekirci kapasiteye karşıllk gelmekte, bu değer de (hem üretim hem de kurulum süreleri stokastik olduğu için) her periyotta makine kapasitesine eşit olmaktadır.

Sadece kurulum sürelerinin stokastik olduğu problem için $C_{t}^{\prime}$ gerekirci toplam üretim süresinin kapasiteden çıarılmasıyla elde edilmektedir $\left(C_{t}^{\prime}=C_{t}-\sum_{i \in P_{t}}\left(v t_{i} x_{i t}\right)\right)$. Eğer makinenin zaman kapasitesi periyod $t$ içerisinde üretim için harcanan toplam süreden küçük ya da eşitse $\left(C_{t} \leq \sum_{i \in P_{t}}\left(v t_{i} x_{i t}\right)\right)$ beklenen ek mesai süresi (25b) denklemi kullanılarak hesaplanmaktadır.

$$
O_{t}\left(\mathbf{x}_{t}, \mathbf{y}_{t}\right)=E\left[Z_{t}\right]+\sum_{i \in P_{t}}\left(v t_{i} x_{i t}\right)-C_{t}
$$




\section{6. Çözüm Yöntemleri}

Bu makalede yüksek kaliteli yaklaşık/sezgisel sonuçlar üretmek için tabu arama metoduna dayanan bir çözüm yaklaşımı önerilmektedir. Bu yaklaşım başlangıç, iyileştirme ve planlama aşamalarından oluşmaktadır. Sonuçların kalitesi literatürde rapor edilen istatiksel alt sınırlar kullanılarak belirlenmektedir. Daha belirgin olarak, stokastik kurulum süreli problem için elde edilen çözümlerin toplam maliyetlerinin, Taş ve diğ. (2019) tarafından bulunan alt sınırlara olan uzaklığı kullanılarak önerilen yaklaşımın performansı değerlendirilmektedir (Bölüm 7.1).

\subsection{Başlangıç Metodu}

Çözüm yaklaşımının bu adımında klasik PBBP modeli kullanılarak olurlu bir başlangıç çözümü oluşturulmaktadır. Daha belirgin olarak, önce (1)-(7) modeli IBM ILOG CPLEX 12.5 (IBM, 2019) eniyileme yazılımı ile çözülmektedir. Diğer bir deyişle, gerekirci PBBP modeli kullanılarak olurlu planlar elde edilmektedir ve bu planların klasik üretim maliyetleri bilinmektedir. Daha sonra, bu planların beklenen ek mesai maliyetleri stokastik üretim ve kurulum sürelerine göre hesaplanmaktadır. Böylelikle, olurlu üretim planlarının toplam beklenen maliyetleri elde edilmektedir.

Literatürde, klasik parti büyüklüğü belirleme modellerinin birçok formülasyonu verilmektedir (bkz. Pochet ve Wolsey, 2006). Denizel ve Süral (2006) makalesinde belirtildiği üzere orijinal versiyonu Krarup ve Bilde (1977) tarafından sunulan ulaşım problemi formülasyonu bütün modeller içerisinde en iyi performansı göstermektedir. Bu formülasyon orijinal modele göre daha iyi bir gevşetilmiş doğrusal programlama boşluğu elde etmektedir (bkz. Pochet ve Wolsey, 2006). Ayrıca, Taş ve diğ. (2019) tarafından sunulan çalışmada da stokastik problem için ulaşım problemi formülasyonunun standart modele göre daha iyi performans gösterdiği raporlanmıştır. Kapasite kısıtlı çok ürünlü dinamik PBBP modelinin ulaşım problemi formülasyonu (Model-UP) aşağıdaki şekilde verilmektedir. Çözüm yaklaşımının ilk aşamasında olurlu başlangıç planları bulmak için bu formülasyon çözülmüştür.

$$
\begin{aligned}
& \min _{i \in P}\left(v c_{i} \sum_{t \in T} \sum_{l=t}^{m} z_{i t l}+s c_{i} \sum_{t \in T} y_{i t}+h c_{i} \sum_{l \in T} \sum_{t=1}^{l-1}(l-t) z_{i t l}\right) \\
& \sum_{t=1}^{l} z_{i t l}=d_{i l}, \quad i \in P, l \in T, \\
& z_{i t l} \leq d_{i l} y_{i t}, \\
& \sum_{i \in P}\left(\sum_{l=t}^{m} v t_{i} z_{i t l}\right)+s t_{i} y_{i t} \leq C_{t}, \quad t \in P, t \in T, l=t, \ldots, m, \\
& z_{i t l} \geq 0, \quad i \in P, t \in T, l=t, \ldots, m, \\
& y_{i t} \in\{0,1\}, \quad i \in P, t \in T .
\end{aligned}
$$

Yukarıdaki modelde, $z_{i t l}$ değişkeni periyot l'de kullanılmak üzere ürün $i$ 'den periyot $t$ içerisinde üretilen birim sayısını göstermektedir $(l \geq t)$. Amaç (26) toplam üretim, kurulum ve envanter maliyetlerini en küçültmektir. (27) kısıt kümesi, ürün $i$ 'in periyot l'deki talebinin periyot $t$ 'ten periyot l'ye kadar yapılan toplam üretim miktarıyla karşılanmasını sağlamaktadır. (28) kısıt kümesi, her üretim koşumu için bir kurulumun gerektiğini göstermektedir. (29) kısıt kümesi, her bir periyotta toplam üretim ve kurulum süresinin makine kapasitesini geçmemesini sağlamaktadır. (30) ve (31) kısıt kümeleri sırasılla, üretim ve kurulum değişkenlerinin değer alanını belirtmektedir.

\subsection{Tabu Arama Metodu}

Meta-sezgisel yöntemler, özellikle Tabu arama metodu, gerekirci parti büyüklüğü belirleme problemleri için yaygın bir şekilde kullanılmaktadır (bkz. Hindi, 1995; Hindi, 1996; Kimms, 1996; Kuik ve diğ., 1993; Gopalakrishnan ve diğ., 2001; Hung ve diğ., 2003). Bu metodun temel adımları için ilgili okuyucu Glover (1989, 1990), Glover ve Laguna (1997), Glover ve Kochenberger (2003), Michalewicz ve Fogel (2002), ve Ribeiro ve Hansen (2001) tarafından sunulan çalışmalara yönelebilir. Bu metodun başarılı bir şekilde çalışması hem esnek olmasına hem de büyük ve karmaşık problemlerin üstesinden gelebilmesine dayanmaktadır. Sonuç olarak, bu metot klasik parti büyüklüğü belirleme probleminin ticari yazılımlarla çözülemeyecek stokastik versiyonları için özellikle uygundur.

$\mathrm{Bu}$ makalede önerilen yaklaşımın ikinci aşamasında, ilk aşamada elde edilen olurlu çözüm tabu arama metodu ile iyileştirilmektedir. $\mathrm{Bu}$ algoritmada, her iterasyona başlarken elimizde toplam beklenen maliyeti $z(g)$ ile belirtilen güncel bir $g$ çözümü bulunmaktadır. İlk iterasyonda güncel çözüm, olurlu başlangıç çözümüne karşılık gelmektedir. Her iterasyonda arama yapmak için $g$ çözümünün bir komşuluk bölgesi oluşturulmaktadır. Bu bölge $k(g)$ ile temsil edilmektedir. Komşuluk bölgesi oluşturulurken uygulanan hareket ürün $i$ 'nin tüm üretim miktarını periyot $t$ 'den alıp önceki bir periyoda (periyot $q$ ) aktarmaktır, $1 \leq$ $q \leq t-1$. Daha belirgin olarak, her bir periyottaki her bir ürün için üretim miktarı sırasıyla önceki periyotlara aktarılmaktadır. 
Komşuluk hareketiyle oluşturulan her bir olurlu çözüm $g^{\prime}$ ile, karşllık gelen toplam beklenen maliyeti de $z\left(g^{\prime}\right)$ ile belirtilmektedir. Algoritmanın her iterasyonunda komşuluk bölgesindeki en iyi çözüm seçilmektedir $\left(g^{*}=\min _{g^{\prime} \in k(g)}\left\{z\left(g^{\prime}\right)\right\}\right)$. Seçilen bu çözüm bir sonraki iterasyonda güncel çözüm olarak kullanılmaktadır. Farz edelim ki seçilen çözüm, ürün $i$ 'nin üretiminin periyot $q$ 'ye aktarılmasiyla oluşturuldu. Bu durumda $(i, q)$ tabu listesine eklenmekte, böylece ürün $i$ 'nin $\vartheta$ iterasyon boyunca üretimi periyot $q$ 'den başka herhangi bir periyoda aktarılmamaktadır. Burada $\vartheta$ tabu listesinin boyutuna karşılık gelmektedir ve amaç halihazırda elde edilmiş çözümlere tekrar dönmeyi olabildiğince engellemektir. Herhangi bir hareketin tabu olma durumu aspirasyon kriterini sağlaması halinde geçersiz kalır. Diğer bir deyişle, eğer bir tabu hareketi algoritma tarafından o ana kadar bulunmuş en iyi çözümden daha iyi bir çözüm elde ediyorsa, tabu hareketine izin verilir.

Önerilen tabu arama algoritmasında orta-vadeli hafıza yapısı uygulanmaktadır. Daha belirgin olarak, algoritmanın bulduğu en iyi çözümün $\eta$ iterasyon boyunca değişmemesi durumunda bu çözüm güncel çözüm olarak belirlenmektedir. Amaç, en iyi çözümün iyileştirme sağlamayan komşuluk bölgelerinden uzaklaşıp başka komşuluk bölgelerinde arama yapmaktır. Diğer bir deyişle, en iyi çözüme daha önceden uygulanmış ve iyileştirme sağlamayan hareketler tabu listesinde tutulmaktadır ve bu hareketler göz ardı edilerek iyileştirme sağlaması muhtemel yeni hareketler uygulanmaktadır.

Tabu algoritmasını durdurmak için iki kriter uygulanmaktadır. Birincisi, algoritmanın $\theta$ iterasyon boyunca devam etmesidir. İkincisi, algoritma tarafından elde edilen en iyi çözümün $\tau$ iterasyon boyunca $(\eta<\tau<\theta)$ güncellenmemesi durumunda algoritma durmaktadır.

\subsection{Planlama Metodu}

Tabu arama metodunda her $\mu$ iterasyonda bir, (32)-(36) doğrusal programlama modeli kullanılarak toplam maliyet iyileştirilmektedir. Güncel çözümün (o iterasyonda elde edilen en iyi çözümün) kurulum değişkenleri modele parametre olarak verilerek en iyi üretim ve envanter değerleri bulunmaktadır. Diğer bir deyişle, her periyotta üretimi yapılan ürünler sabit tutularak üretim ve envanter maliyetleri en küçüklenmektedir. Bu sayede, tabu metodunun elde ettiği çözümler için planlama yapılarak iyileştirme sağlanmaktadır. Bu modelde $a_{i t}$ parametresi ürün $i$ güncel çözümün $t$ periyodu içerisinde üretiliyorsa 1 , üretilmiyorsa 0 değerini almaktadır.

$$
\begin{aligned}
& \min \sum_{i \in P}\left(v c_{i} \sum_{t \in T} \sum_{l=t}^{m} z_{i t l}+h c_{i} \sum_{l \in T} \sum_{t=1}^{l-1}(l-t) z_{i t l}\right) \\
& \sum_{t=1}^{l} z_{i t l}=d_{i l}, \\
& z_{i t l} \leq d_{i l} a_{i t}, \quad i \in P, l \in T, \\
& \sum_{i \in P}\left(\sum_{l=t}^{m} v t_{i} z_{i t l}\right)+s t_{i} a_{i t} \leq C_{t}, \quad t \in P, t \in T, l=t, \ldots, m, \\
& z_{i t l} \geq 0, \quad i \in P, t \in T, l=t, \ldots, m .
\end{aligned}
$$

\section{Hesaplamalı Deneyler}

$\mathrm{Bu}$ çalışmada hesaplamalı deneyler Trigeiro ve diğ. (1989) tarafından gerekirci PBBP için geliştirilmiş olan veri setleri üzerinden yapılmaktadır. Bu çalışmada, kurulum süreleri uzun ve kapasite kullanımı orta seviyede olan 20 ve 30 ürünlü 60 problem örneğine odaklanılmıştır. Trigeiro ve diğg. (1989) her problem örneğinde makinenin zaman kapasitesinin tüm periyotlar için aynı olduğunu farz etmişlerdir. Ayrıca, problem örneklerinde birim üretim maliyeti sıfira eşitlenmiş̧tir. Öyle ki, ele alınan problemde tüm talepler karşılanmalıdır ve üretim maliyetleri zamana bağlı değildir. Bundan dolayı, toplam üretim maliyeti sabit bir değere karşllık gelmektedir ve herhangi bir matematiksel modelde ya da çözüm prosedüründe ele alınmasına gerek kalmamaktadır.

Hesaplamalı deneylerin ilk aşamasında, Gama dağılımının parametreleri beklenen sürelerin orijinal sürelere eşit olmasını sağlayacak şekilde değerler almaktadır $(\alpha \lambda=1, \alpha=0.0625$ ve $\lambda=16)$. Bu değerlere göre birim süre için göz önünde bulundurulan belirsizlik katsayısı 4'e eşit olmaktadır. Ek mesai süresi için ortaya çıkan birim maliyet $\left(o c_{t}\right)$ Taş ve diğ. (2019) tarafindan önerilen prosedüre göre hesaplanmaktadır. Daha belirgin olarak, her bir periyottaki toplam envanter tutma ve kurulum maliyeti ekonomik sipariş miktarı (EOQ) yaklaşımı kullanılarak hesaplanmaktadır. Elde edilen maliyet daha sonra toplam kapasiteye bölünmektedir. Diğer bir deyişle, ele alınan problem örneklerinde her $t$ periyodu için kullanılacak olan birim ek mesai maliyeti (37) denklemi kullanılarak hesaplanmaktadır. Bu denklemde $\rho$ parametresinin değeri yapılan ön testlerin sonucuna göre 50 olarak belirlenmiştir. Ayrıca, $\bar{d}_{l}$ ürün $i$ için ortalama talep miktarına karşıılık gelmektedir ve (38) denklemi kullanılarak hesaplanmaktadır.

$$
\text { 国回 }=\rho \frac{\sum_{i \in P} \sqrt{2 \bar{d}_{l} s c_{i} h c_{i}}}{C_{t}}
$$




$$
\overline{d_{\imath}}=\frac{\sum_{t \in T} d_{i t}}{m}
$$

Tabu arama metodunun parametreleri şu şekilde değerler almaktadır: $\theta=1000, \eta=20, \tau=100, \vartheta=15, \mu=10 . \mathrm{Bu}$ parametreler, farklı değerler kullanılarak yapılan ön deneylerde elde edilen çözümlerin analiz edilmesiyle belirlenmiştir. Bu projede çözüm yöntemleri C++ programıyla kodlanmış ve matematiksel modeller IBM ILOG CPLEX 12.5 (IBM, 2019) kullanılarak çözülmüştür. Matematiksel modellerin CPLEX ile çözümünde zaman limiti 15 dakika olarak belirlenmiştir. Ayrıca, tüm deneyler işletimcisi $2.7 \mathrm{GHz}$ Intel Core i5 ve hafızası 8 GB olan MacBook Pro ile yapılmıştır.

\subsection{Stokastik Kurulum Süreleri İçeren PBBP}

Önerilen çözüm yöntemlerinin performansını değerlendirmek için öncelikle üretim süreleri gerekirci, fakat kurulum süreleri stokastik olan PBBP ele alınmıştır. Diğer bir deyişle, Taş ve diğ. (2019) tarafından çalışılan problem tabu arama metoduyla çözdürülmüştür. Amaç, yazarların ortalama numune yaklaşımı ile elde ettikleri alt sınır değerlerini kullanarak bu çalışmada bulunan sonuçların kalitesini ölçmektir. Tablo 1'de başlangıç çözümleri ve Tablo 2'de tabu arama metodunun bulduğu çözümler detaylı olarak sunulmaktadır. Tablo 1'de kolonların açıklaması şu şekildedir: "Ürün” ele alınan problem örneklerindeki ürün sayısını, "TÜ" toplam üretim miktarını, "TK" toplam kurulum sayısını, "TE” toplam envanteri, "BMS” toplam beklenen ek mesai süresini, "TGM” toplam gerekirci maliyeti, "BMM" toplam beklenen ek mesai maliyetini, "TM" toplam maliyeti ve "Süre" CPLEX tarafından çözüm bulmak için harcanan toplam süreyi (saniye cinsinden) belirtmektedir. Tablo 2'de ise "Süre" tabu arama algoritması durana kadar geçen süreyi (saniye cinsinden) göstermektedir. Ayrıca her iki tabloda, bulunan sonuçların amaç fonksiyonu değerlerinin Taş ve diğ. (2019) tarafından rapor edilen alt sınır değerlerine uzaklıkları "ASU (\%)" kolonunda belirtilmektedir. Tüm bu değerler veri setlerinin içerdiği problem örnekleri üzerinden ortalama alınarak raporlanmaktadır.

Tablo 1'de detayları verilen çözümlerin hepsi eniyi sonuçlardır. Diğer bir deyişle, CPLEX tüm problem örnekleri için eniyi gerekirci çözümü bulabilmiştir. İlk ve ikinci satırdaki sonuçlar 20 ürünlü ve 30 ürünlü problem örnekleri üzerinden alınan ortalama değerleri, "Ort." satırındaki sonuçlar tüm problem örnekleri üzerinden alınan ortalama değerleri göstermektedir. 20 ürün içeren problem örnekleri için bulunan çözümlerin amaç fonksiyon değerlerinin Taş ve diğ. (2019) tarafından rapor edilen alt sınırlara olan uzaklığg \%19,03'tür. 30 ürünlü problem örnekleri için bu fark \%15,59'dur. Tüm problem örnekleri için elde edilen çözümlere bakıldığında, alt sınıra olan uzaklığın \%17,31 olduğu görülmektedir. Alt sınırlara olan bu uzaklıklar göstermektedir ki, stokastik kurulum sürelerinin planlama aşamasında modellemeye dahil edilmemesi, elde edilen çözümlerin stokastik ortamlarda oldukça kötü performans göstermesine sebep olmaktadır. Ayrıca, Tablo 1'deki sonuçlardan görülmektedir ki, beklenen ek mesai süresi 20 ürünlü problem örnekleri için ortalama 121,08 ve 30 ürünlü problem örnekleri için ortalama 145,57 birimdir. Tüm problem örnekleri incelendiğinde, beklenen ek mesai süresinin ortalama 133,33 olduğu görülmektedir. Diğer bir deyişle, gerekirci çözümler kurulum sürelerinin stokastik olduğu ortamlarda uygulandığında makina kapasitesi aşılmaktadır. Bu sebeple, makina kapasitesinin aşılmasına izin verilmeyen gerekirci ortamlar için klasik modellerin ürettiği planların olurlu olmadığı sonucuna varılmaktadır.

Tablo 1. Model-SF ile sadece kurulum süreleri stokastik olan PBBP için elde edilen başlangıç çözümlerinin detayları $(\alpha=0,0625$ ve $\lambda=16)$.

\begin{tabular}{c|c|c|c|c|c|c|c|c|c}
\hline Ürün & TÜ & TK & TE & BMS & TGM & BMM & TM & Süre & ASU (\%) \\
\hline 20 & 35919,07 & 187,23 & 21038,73 & 121,08 & 60837,21 & 9941,96 & 70779,19 & 86,31 & $\% 19,03$ \\
\hline 30 & 53995,10 & 283,27 & 30161.37 & 145,57 & 89945,65 & 12531,26 & 102476,91 & 147,24 & $\% 15,59$ \\
\hline Ort. & 44957,08 & 235,25 & 25600,05 & 133,33 & 75391,43 & 11236,61 & 86628,05 & 116,77 & $\% 17,31$ \\
\hline
\end{tabular}

Tablo 2. Tabu arama metodu ile sadece kurulum süreleri stokastik olan PBBP için elde edilen çözümlerin detayları $(\alpha=0,0625$ ve $\lambda=16)$.

\begin{tabular}{c|c|c|c|c|c|c|c|c|c}
\hline Ürün & TÜ & TK & TE & BMS & TGM & BMM & TM & Süre & ASU (\%) \\
\hline 20 & 35919,07 & 176,60 & 24178,30 & 15,45 & 62344,20 & 1935,06 & 64279,29 & 58,39 & $\% 3,56$ \\
\hline 30 & 53995,10 & 269,73 & 34945,87 & 12,46 & 91854,65 & 1683,19 & 95537,87 & 98,77 & $\% 2,49$ \\
\hline Ort. & 44957,08 & 223,17 & 29562,08 & 13,96 & 77099,43 & 1809,13 & 78908,58 & 78,58 & $\% 3,03$ \\
\hline
\end{tabular}

Tablo 2'de verilen sonuçlar göstermektedir ki başlangıç çözümüne göre tabu arama metodu amaç fonksiyonu değeri (toplam maliyet) üzerinden 20 ürün içeren veri seti için \%9,18'lik ve 30 ürün içeren veri seti için \%6,77’lik bir iyileşme sağlamıştır. Amaç fonksiyonu değerine göre tüm problem örnekleri üzerinden ise \%8,91'lik bir iyileşme görülmektedir. Başlangıç çözümüyle karşılaştırıldığında, tabu arama metodu ile bulunan çözümlerde envanter sayısı artmış, fakat kurulum sayısı azalmıştır. Daha belirgin olarak, başlangıç çözümüne göre tabu arama metodunun elde ettiği çözümlerde toplam envanter üzerinden 20 ürün içeren veri seti için $\% 14,92$ 'lik ve 30 ürün içeren veri seti için \%15,86'lık bir artış görülmektedir. Toplam envantere göre tüm problem örnekleri 
üzerinden ise \%15,48'lik bir artış tespit edilmektedir. Envanter sayısındaki artış, kurulum sayısında azalma sağlamıştır. Diğer bir deyişle, başlangıç çözümüne göre toplam kurulum sayısı üzerinden 20 ürün içeren veri seti için $\% 5,68$ 'lik ve 30 ürün içeren veri seti için \% $4,78^{\prime}$ lik bir azalma görülmektedir. Toplam kurulum sayısına göre tüm problem örnekleri üzerinden ise \%5,14'lük bir azalma tespit edilmektedir. Bu azalmanın etkisiyle beklenen ek mesai süresinde ciddi bir azalma olmuştur. Daha belirgin olarak, başlangıç çözümüne göre beklenen ek mesai süresi üzerinden 20 ürün içeren veri seti için $\% 87,24$ 'lük ve 30 ürün içeren veri seti için \%91,44'lük bir iyileşme sağlanmıştır. Beklenen ek mesai süresine göre tüm problem örnekleri üzerinden ise \%89,53'lük bir iyileşme görülmektedir. Bu durum da toplam beklenen maliyeti düşürmüştür. Başlangıç çözümüne göre toplam beklenen maliyet üzerinden 20 ürün içeren veri seti için \%80,54'lük ve 30 ürün içeren veri seti için \%86,57'lik bir iyileşme sağlanmıştır. Beklenen toplam maliyete göre tüm problem örnekleri üzerinden ise $\% 83,90^{\prime}$ lık bir iyileşme görülmektedir. Ayrıca, çözümler çok kısa süreler içerisinde bulunabilmektedir: 20 ürün içeren veri seti için harcanan ortalama süre 58,39 saniye, 30 ürün içeren veri seti için harcanan ortalama süre 98,77 saniye ve tüm problem örnekleri için harcanan ortalama süre 78,58 saniyedir.

Ek olarak, 20 ürün içeren problem örnekleri için bulunan çözümlerin Taş ve diğ. (2019) tarafından rapor edilen alt sınırlara olan uzaklığ $1 \% 3,56$ 'dır. 30 ürünlü problem örnekleri için bu değer daha da düşüktür $(\% 2,49)$. Tüm problem örnekleri için elde edilen çözümlere bakıldığında, alt sınıra olan uzaklığın \%3,03 olduğu görülmektedir. Ayrıca, alt sınırların bulunmasını sağlayan prosedür 20 ürünlü problem örneklerini ortalama 1022,72 saniyede, 30 ürünlü problem örneklerini ortalama 941,07 saniyede ve tüm problem örneklerini ortalama 981,89 saniyede çözmektedir (Taş ve diğ., 2019). Diğer bir deyişle, bu makalede önerilen çözüm yöntemi Taş ve diğ. (2019) tarafindan rapor edilen süreler baz alındığında 20 ürünlü problem örnekleri için ortalama $\% 94,29,30$ ürünlü problem örnekleri için ortalama $\% 89,50$ ve tüm problem örnekleri için ortalama $\% 92,00$ iyileşme sağlamaktadır. Bu sonuçlar göstermektedir ki, tabu arama metodu hem bulunan çözümlerin kalitesi hem de harcanan süre açısından oldukça iyi bir performans sergilemektedir.

\subsection{Stokastik Üretim ve Kurulum Süreleri İçeren PBBP}

Deneylerin ikinci aşamasında, bu makalede tanıtılan problem tabu arama metoduyla çözülmüştür. Başlangıç çözümünün detayları Tablo 3’te verilmektedir. Görüldüğü üzere, bu çözümlerin gerekirci detayları Tablo 1'de verilen çözümlerle aynıdır. Bunun sebebi şu şekildedir: Üretim sürelerinin stokastik olması gerekirci çözümü değiştirmemektedir ve gerekirci PBBP için CPLEX ile elde edilen çözümler iki problem için de geçerlidir. Bir başka deyişle, stokastik kurulum süreleri içeren PBBP için bulunan başlangıç çözümleri, stokastik üretim ve kurulum süreleri içeren PBBP için de başlangıç çözümleri olarak kullanılmıştır ve bu sebeple gerekirci detaylar (çözüm süresi de dahil olmak üzere) her iki tabloda aynıdır. Farklılık, beklenen ek mesai süresi ve beklenen maliyette ortaya çıkmaktadır. Tablo 1'de bulunan çözümler üretim sürelerinin de stokastik olduğu ortamda değerlendirilmişlerdir. Kurulum sürelerine ek olarak üretim sürelerinin de stokastik olması, beklenen ek mesai süresi, beklenen ek mesai maliyeti ve toplam beklenen maliyette artışa sebep olmaktadır.

Tablo 4'te verilen sonuçlar göstermektedir ki başlangıç çözümüne göre tabu arama metodu amaç fonksiyonu değeri (toplam maliyet) üzerinden 20 ürün içeren veri seti için $\% 25,93$ 'lük ve 30 ürün içeren veri seti için \%30,32'lik bir iyileşme sağlamıştır. Amaç fonksiyonu değerine göre tüm problem örnekleri üzerinden ise $\% 28,44$ 'lük bir iyileşme görülmektedir. Başlangıç çözümüyle karşılaştırıldığında, tabu arama metodu ile bulunan çc̈zümlerde envanter sayısı artmış, fakat kurulum sayısı azalmıştır. Daha belirgin olarak, başlangıç çözümüne göre tabu arama metodunun elde ettiği çözümlerde toplam envanter üzerinden 20 ürün içeren veri seti için $\% 48,19^{\prime} l$ luk ve 30 ürün içeren veri seti için $\% 43,96$ 'llk bir artı̧ görülmektedir. Toplam envantere göre tüm problem örnekleri üzerinden ise \%45,70'lik bir artış tespit edilmektedir. Envanter sayısındaki artış, kurulum sayısında azalma sağlamıştır. Diğer bir deyişle, başlangıç çözümüne göre toplam kurulum sayısı üzerinden 20 ürün içeren veri seti için $\% 14,05^{\prime}$ lik ve 30 ürün içeren veri seti için \%11,81'lik bir azalma görülmektedir. Toplam kurulum sayısına göre tüm problem örnekleri üzerinden ise $\% 12,70$ 'lik bir azalma tespit edilmektedir. Bu azalmanın etkisiyle beklenen ek mesai süresinde ciddi bir azalma olmuştur. Daha belirgin olarak, başlangıç çözümüne göre beklenen ek mesai süresi üzerinden 20 ürün içeren veri seti için $\% 71,15$ 'lik ve 30 ürün içeren veri seti için \% 83,31 'lik bir iyileşme sağlanmıştır. Beklenen ek mesai süresine göre tüm problem örnekleri üzerinden ise \%77,18'lik bir iyileşme görülmektedir. Bu durum da toplam beklenen maliyeti düşürmüştür. Başlangıç çözümüne göre toplam beklenen maliyet üzerinden 20 ürün içeren veri seti için $\% 61,66^{\prime}$ lık ve 30 ürün içeren veri seti için $\% 77,83$ 'lük bir iyileşme sağlanmıştır. Beklenen toplam maliyete göre tüm problem örnekleri üzerinden ise \%70,43'lük bir iyileşme görülmektedir.

Ayrıca, 20 ürün içeren veri seti için harcanan ortalama süre 63,22 saniye, 30 ürün içeren veri seti için harcanan ortalama süre 115,67 saniye ve tüm problem örnekleri için harcanan ortalama süre 89,44 saniyedir. Bu sonuçlar göstermektedir ki, tabu arama metodu makalede önerilen problem için oldukça kısa sürelerde ve gerekirci modellerin sağladığı çözümlerle kıyaslandığında oldukça yüksek kaliteli sonuçlar elde etmektedir.

Sonuç olarak, hesaplamalı deneyler göstermektedir ki, önerilen çözüm yöntemleri hem sadece kurulum sürelerinin stokastik olduğu problem için (Bölüm 7.1), hem de literatüre bu makalede tanıtılmış olan üretim ve kurulum sürelerinin stokastik olduğu versiyon için kısa sürelerde oldukça iyi (stokastik ortamda iyi performans sergileyen) sonuçlar elde etmektedir.

Tablo 3. Model-SF ile üretim ve kurulum süreleri stokastik olan PBBP için elde edilen başlangıç çözümlerinin detayları $(\alpha=0,0625$ ve $\lambda=16)$.

\begin{tabular}{c|c|c|c|c|c|c|c|c}
\hline Ürün & TÜ & TK & TE & BMS & TGM & BMM & TM & Süre \\
\hline 20 & 35919,07 & 187,23 & 21038,73 & 624,17 & 60837,21 & 61665,27 & 122502,57 & 86,31 \\
\hline 30 & 53995,10 & 283,27 & 30161.37 & 730,91 & 89945,65 & 73126,70 & 163072,29 & 147,24 \\
\hline Ort. & 44957,08 & 235,25 & 25600,05 & 677,54 & 75391,43 & 67395,98 & 142787,43 & 116,77 \\
\hline
\end{tabular}


Tablo 4. Tabu arama metodu ile üretim ve kurulum süreleri stokastik olan PBBP için elde edilen çözümlerin detayları

\begin{tabular}{|c|c|c|c|c|c|c|c|c|}
\hline Ürün & TÜ & TK & TE & BMS & TGM & BMM & TM & Süre \\
\hline 20 & 35919,07 & 160,93 & 31179,00 & 180,09 & 67103,71 & 23639,86 & 90743,58 & 63,22 \\
\hline 30 & 53995,10 & 249,83 & 43420,17 & 129,29 & 97414,43 & 16213,40 & 113627,82 & 115,67 \\
\hline Ort. & 44957,08 & 205,38 & 37299,58 & 154,59 & 82259,07 & 19926,63 & 102185,70 & 89,44 \\
\hline
\end{tabular}

\section{Sonuçlar}

$\mathrm{Bu}$ makalede literatüre stokastik üretim ve kurulum süreleri içeren kapasite kısıtlı çok ürünlü dinamik parti büyüklüğü belirleme problemi tanıtılmıştır. Bu problemin amacı klasik üretim maliyetleri ve beklenen ek mesai maliyetlerinden oluşan toplam maliyeti enküçüklemektir. Belirli bir üretim ve kurulum planı için beklenen ek mesai süresini kesin olarak hesaplayan bir prosedür geliştirilmiştir. Ayrıca, ele alınan problemi çözmek için üç aşamadan oluşan bir yaklaşım önerilmiştir. İlk aşamada olurlu bir başlangıç çözümü bulunmaktadır. Bu çözüm tabu arama metodu ile iyileştirilmektedir. Belirli iterasyonlarda doğrusal bir matematiksel model kullanılarak toplam maliyet düşürülmektedir. Diğer bir deyişle, üçüncü aşamada planlama yapılmakta, sabit kurulum değişkenlerine göre üretim ve envanter maliyetleri enküçüklenmektedir.

Hesaplamalı deneylerin ilk aşamasında sadece kurulum sürelerinin stokastik olduğu problem çözdürülmüştür. Bu problem için elde edilen sonuçların literatürde raporlanan alt sınırlardan ortalama uzaklığı \%3,03’tür. Ayrıca, başlangıç adımı olarak alınan gerekirci çözümlere göre toplam maliyet üzerinden ortalama $\% 8,91$ 'lik iyileşme sağlanmıştır. İkinci aşamada hem üretim hem kurulum sürelerinin stokastik olduğu problem ele alınmıştır. Tabu arama metodu gerekirci çözüme göre toplam maliyet üzerinden tüm problem örnekleri için ortalama \%28,44'lük bir iyileşme sağlamaktadır. İki problem için de harcanan süreler oldukça kısadır. Diğer bir deyişle, önerilen çözüm yöntemi hem elde edilen çözümlerin kalitesi hem de harcanan süre açısından oldukça iyi bir performans göstermektedir.

Bundan sonraki çalışmalarda, ele alınan problem kesin yöntemler kullanılarak veya alt sınır değerleri verebilecek bir prosedür geliştirilerek (örneğin, ortalama numune yaklaşımı) çözülebilir. Bir başka çalışma alanı, stokastik sürelerin ele alındığı probleme stokastik taleplerin eklenmesi olarak düşünülebilir.

\section{Kaynakça}

Aloulou, M.A., Dolgui, A. ve Kovalyov, MY. (2014) A bibliography of nondeterministic lot-sizing models, International Journal of Production Research, 52, 2293-2310. doi: 10.1080/00207543.2013.855336

Barbarosoğlu, G. ve Özdamar, L. (2000) Analysis of solution space-dependent performance of simulated annealing: the case of the multi-level capacitated lot sizing problem, Computers and Operations Research, 27, 895-903. doi: 10.1016/S0305-0548(99)00064-7

Beraldi, P., Ghiani, G., Guerriero, E. ve Grieco, A.(2006) Scenario-based planning for lot-sizing and scheduling with uncertain processing times, International Journal of Production Economics, 101, 140-149. doi: 10.1016/j.ijpe.2005.05.018

Birge, J.R. ve Louveaux, F. (2011) Introduction to Stochastic Programming, Springer Series in Operations Research and Financial Engineering.

Bitran, G.R. ve Yanesse, H.H. (1982) Computational complexity of the capacitated lot size problem, Management Science, 28, 11741186. doi: $10.1287 / \mathrm{mnsc} .28 .10 .1174$

Bookbinder, J.H. ve Tan, J.Y. (1988) Strategies for the probabilistic lot-sizing problem with service-level constraints, Management Science, 34, 1096-1108. doi: 10.1287/mnsc.34.9.1096

Brahimi, N., Dauzere-Peres, S., Najid ve N.M., Nordli, A. (2006) Single item lot sizing problems, European Journal of Operational Research, 168, 1-16. doi: 10.1016/j.ejor.2004.01.054

Brahimi, N., Absi, N., Dauzère-Pérès, S. ve Nordli, A. (2017) Single-item dynamic lot-sizing problems: An updated survey, European Journal of Operational Research, 263, 838-863. doi: 10.1016/j.ejor.2017.05.008

Brandimarte, P. (2006) Multi-item capacitated lot-sizing with demand uncertainty, International Journal of Production Research, 44, 2997-3022. doi: 10.1080/00207540500435116

Buschkühl, L., Sahling, F., Helber, S. ve Tempelmeier, H. (2010) Dynamic capacitated lot-sizing problems: a classification and review of solution approaches, OR Spectrum, 32, 231-261. doi: 10.1007/s00291-008-0150-7

Dellaert, N.P. ve Melo, M.T. (1998) Make-to-order policies for a stochastic lot sizing problem using overtime, International Journal of Production Economics, 56-57, 79-97. doi: 10.1016/S0925-5273(98)00053-X

Dellaert, N, de Kok, A.G. ve Wei, W. (2000) Push and pull strategies in multistage assembly systems, Statistica Neerlandica, 54, 175189. doi: 10.1111/1467-9574.00135 
Denizel, M. ve Süral, H. (2006) On alternative mixed integer programming formulations and LP-based heuristics for lot-sizing with setup times, Journal of the Operational Research Society, 57, 389-399. doi: 10.1057/palgrave.jors.2601996

Diaby, M., Bahl, H.C., Karwan, M.H. ve Zionts, S. (1992a) Capacitated lot-sizing and scheduling by lagrangean relaxation, European Journal of Operational Research 59, 444-458. doi: 10.1016/0377-2217(92)90201-J

Diaby, M., Bahl, H.C., Karwan, M.H. ve Zionts, S. (1992b) A lagrangean relaxation approach for very-large-scale capacitated lotsizing, Management Science, 38, 1329-1340. doi: 10.1287/mnsc.38.9.1329

Glover, F. (1989) Tabu search - Part I, ORSA Journal on Computing, 1, 190-206. doi: 10.1287/ijoc.1.3.190

Glover, F. (1990) Tabu search - Part II, ORSA Journal on Computing, 2, 4-32. doi: 10.1287/ijoc.2.1.4

Glover, F. ve Laguna, M. (1997) Tabu search. Kluwer Academic Publishers, Boston.

Glover F, Kochenberger GA. Handbook of metaheuristics. Kluwer Academic Publishers, Boston, 2003.

Gopalakrishnan, M., Ding, K., Bourjolly, J.M. ve Mohan, S. (2001) A tabu-search heuristic for the capacitated lot-sizing problem with set-up carryover, Management Science, 47(6), 851-863. doi: 10.1287/mnsc.47.6.851.9813

Hindi, K.S. (1995) Solving the single-item, capacitated dynamic lot sizing problem with startup and reservation costs by tabu search, Computers \& Industrial Engineering, 28, 701-707. doi: 10.1016/0360-8352(95)00027-X

Hindi, K.S. (1996) Solving the CLSP by a tabu search heuristic, Journal of the Operational Research Society, 47, 151-161. doi: 10.1057 /jors. 1996.13

Hindi, K.S., Fleszar, K. ve Charalambous, C. (2003) An effective heuristic for the CLSP with set-up times, Journal of the Operational Research Society, 54, 490-498. doi: 10.1057/palgrave.jors.2601525

Hung, Y.F., Chen, C.P., Shih C.C. ve Hung M.H. (2003) Using tabu search with ranking candidate list to solve production planning problems with setups, Computers \& Industrial Engineering, 45, 615-634. doi: 10.1016/j.cie.2003.09.006

IBM, ILOG CPLEX Optimizer 12.5, http://www-01.ibm.com/ software/integration/optimization/cplex-optimizer, 2019.

Jans, R. ve Degraeve, Z. (2004) Improved lower bounds for the capacitated lot sizing problem, Operations Research Letters, 32, 185195. doi: 10.1016/j.orl.2003.06.001

Jans, R. ve Degraeve, Z. (2007) Meta-heuristics for dynamic lot sizing: a review and comparison of solution approaches, European Journal of Operational Research, 177, 1855-1875. doi: 10.1016/j.ejor.2005.12.008

Jans, R. ve Degraeve, Z. (2008) Modeling industrial lot sizing problems: a review, International Journal of Production Research, 46, 1619-1643. doi: 10.1080/00207540600902262

Jeunet, J. ve Jonard, N. (2000) Measuring the performance of lot-sizing techniques in uncertain environments, International Journal of Production Economics, 64, 197-208. doi: 10.1016/S0925-5273(99)00058-4

Kimms, A. (1996) Competitive methods for multi-level lot sizing and scheduling: tabu search and randomized regrets, International Journal of Production Research, 34, 2279-2298. doi: 10.1080/00207549608905025

Koca, E., Yaman, H., Aktürk, M.S. (2015) Stochastic lot sizing problem with controllable processing times, Omega, 53, 1-10. doi: 10.1016/j.omega.2014.11.003

Krarup, J. ve Bilde, O. (1977) Plant location, set covering and economic lot sizes: an O(mn) algorithm for structured problems. Editors: Collatz L, Meinardus G, Wetterling W. Optimierung bei Graphentheoretischen und Ganzzahligen Probleme, Numerische Methoden bei Optimierungsverfahren, Band 3, 155-179, Birkhauser Verlag, Basel.

Kuhn, H. (1997) A dynamic lot sizing model with exponential machine breakdowns, European Journal of Operational Research, 100, 514-536. doi: 10.1016/S0377-2217(96)00136-1

Kuik, R., Salomon, M., Van Wassenhove, L.N. ve Maes, J. (1993) Linear programming, simulated annealing and tabu search heuristics for lotsizing in bottleneck assembly systems, IIE Transactions, 25, 62-72. doi: 10.1080/07408179308964266

Michalewicz, Z. ve Fogel, D.B. (2002) How to solve it: modern heuristics. Springer-Verlag, Berlin.

Nourelfath, M. (2011) Service level robustness in stochastic production planning under random machine breakdowns, European Journal of Operational Research, 212, 81-88. doi: 10.1016/j.ejor.2011.01.032

Özdamar, L. ve Barbarosoğlu, G. (1999) Hybrid heuristics for the multi-stage capacitated lot sizing and loading problem, Journal of the Operational Research Society, 50, 810-825.

Özdamar, L. ve Birbil, Ş.I. (1998) Hybrid heuristics for the capacitated lot sizing and loading problem with setup times and overtime decisions, European Journal of Operational Research, 110, 525-547. doi: 10.1016/S0377-2217(97)00269-5

Pochet, Y. ve Wolsey, L.A. (2006) Production planning by mixed integer programming. Springer.

Ribeiro, C. ve Hansen, P. (2001) Essays and surveys in metaheuristics. Kluwer Academic Publishers, Dordrecht, The Netherlands.

Süral, H., Denizel, M., Van Wassenhove ve L.N. (2009) Lagrangean relaxation based heuristics for lot sizing with setup times, European Journal of Operational Research, 194, 51-63. doi: 10.1016/j.ejor.2007.11.052

Taş, D., Dellaert, N., Van Woensel, T. ve de Kok, T. (2013) Vehicle routing problem with stochastic travel times including soft time windows and service costs, Computers \& Operations Research, 40, 214-224. doi: 10.1016/j.cor.2012.06.008 
Taş, D., Gendreau, M., Jabali, O. ve Jans, R. (2019) A capacitated lot sizing problem with stochastic setup times and overtime, European Journal of Operational Research, 273(1), 146-159. doi: 10.1016/j.ejor.2018.07.032

Tempelmeier, H. (2013) Stochastic lot sizing problems. Editors: Smith JM, Tan B. Handbook of stochastic models and analysis of manufacturing system operations, International Series in Operations Research \& Management Science, Volume 192, 313-344, New York, Springer.

Trigeiro, W., Thomas, L. ve McClain, J. (1989) Capacitated lot sizing with setup times, Management Science, 35, 353-366. doi: $10.1287 / \mathrm{mnsc} .35 .3 .353$ 